\title{
Dispersion analysis of carbon monoxide concentrations in the linear cities atmospheric air
}

\author{
Julia Ivanova ${ }^{1, *}$, Ekaterina Sokolova ${ }^{2}$, Valery Azarov $^{1}$, Elizaveta Martynova $^{1}$ \\ ${ }^{1}$ Volgograd State Technical University (VolgSTU), 400074, Volgograd, Russia \\ ${ }^{2}$ North Caucasus Federal University (NCFU), 355000, Stavropol, Russian
}

\begin{abstract}
Volgograd belongs to a number of cities in which a linear planning structure was formed, stretching along the Volga River for almost $100 \mathrm{~km}$, however, the width of Volgograd in some sections ranges from 3 to $10 \mathrm{~km}$. The total area outlined by the borders is $400 \mathrm{~km}^{2}$, Volgograd has a "loose" structure, as a result, the territory occupied by residential quarters is almost 3 times smaller. In the city there are gaps between the districts, which are occupied by green areas and wastelands. In Volgograd, large green space arrays prevail on the ravines and gullies slopes, which are widespread in the city, as well as in watershed areas, while having a soilprotective and water-regulating value. Moreover, in general, in Volgograd, the area of green areas is much less than the normative.
\end{abstract}

\section{Introduction}

The industrial center - Volgograd is located at the junction of three geomorphological regions: the Volga Upland, Ergeni and the Caspian Lowland, divided by the Volga River Valley. Volgograd is located on its right bank and borders with Gorodishchensky, Sredneahtubinsky, Svetloyarsky and Kalachevsky districts of the Volgograd region, it is a large transport hub connecting different regions of Russia. As a result, a large number of heavy cargo trucks, transit vehicles moving through different regions of Russia pass through Volgograd [2, 4, 5]. Geographically, Volgograd is divided into 8 administrative regions: Traktorozavodsky, Krasnooktyabrsky, Central, Dzerzhinsky, Voroshilovsky, Sovietskiy, Kirovsky, Krasnoarmeysky, in whose territory industrial enterprises are concentrated. The main air pollution sources include automobile transport and the following industries: ferrous and non-ferrous metallurgy, energy, oil refining, chemical, coal and gas industries. In 2018, the following main stationary pollution sources in Volgograd are the following enterprises: LLC "LUKOIL-Volgogradneftepererabotka", LLC "LUKOIL-Volgogradenergo" Volgograd TPP-2, CJSC "Confil”, OJSC "Volgogradneftemash", ELTEZA OJSC, branch "Volgograd aluminum smelter "RUSAL Volgograd ”, JSC “Caustic ”, LLC “Medecoprom”, LLC “Raduga Zinc List”, etc. [2].

*Corresponding author: ypi26@mail.ru 


\section{Results}

According to the Office of the Federal Service for Supervision of Natural Resources Management (Rosprirodnadzor) in the Volgograd Region, the mass of pollutant emissions into the atmosphere from stationary sources in the region amounted to 141,5 thousand tons, which is 3,5 thousand tons $(2.5 \%)$ more than in 2017 . The dominant position in the emissions structure is occupied by liquid and gaseous substances $(95 \%)$, of which carbon monoxide is $43 \%$, hydrocarbons (without VOCs) $23 \%$, and nitrogen oxides $15,2 \%$. The largest enterprises are concentrated in Volgograd and Volzhsky. In 2018, they accounted for 27,9 thousand tons and 49,7 thousand tons pollutants entering the atmosphere, respectively [2]. The main indicators of gross pollutants emissions, entering the atmospheric air in the Volgograd region, are presented for the time period 2014 in table.1.

Table 1. Dynamics of gross pollutants emissions into the air in the Volgograd region from 20142018.

\begin{tabular}{|l|l|l|l|l|l|}
\hline Emission indicators & 2014 & 2015 & 2016 & 2017 & 2018 \\
\hline Total, thousand tons/year & 153.5 & 159.9 & 161.4 & 138.0 & 141.5 \\
\hline Including: & & & & & \\
\hline solid & 9.95 & 10.0 & 8.9 & 8.7 & 6.6 \\
\hline gaseous and liquid, of which: & 143.6 & 149.9 & 152.5 & 129.3 & 134.9 \\
\hline sulfur dioxide & 7.2 & 7.6 & 12.1 & 7.4 & 7.5 \\
\hline carbon monoxide & 56.7 & 60.8 & 54.5 & 54.3 & 58.1 \\
\hline nitrogen oxides & 25.4 & 27.3 & 26.2 & 25.4 & 20.5 \\
\hline hydrocarbons (without VOCs) & 28.6 & 28.1 & 39.0 & 22.7 & 31.4 \\
\hline VOC & 22.5 & 23.1 & 17.4 & 17.8 & 16.3 \\
\hline other gaseous and liquid & 3.1 & 3.2 & 3.2 & 1.6 & 1.1 \\
\hline
\end{tabular}

As can be seen from the table, in 2018 there is an excess compared to 2017 emissions, such as carbon monoxide by 3,8 thousand tons/g; sulfur dioxide per 0,1 thousand tons/g; hydrocarbons (without VOC) at 8,7 thousand tons/year. [2].

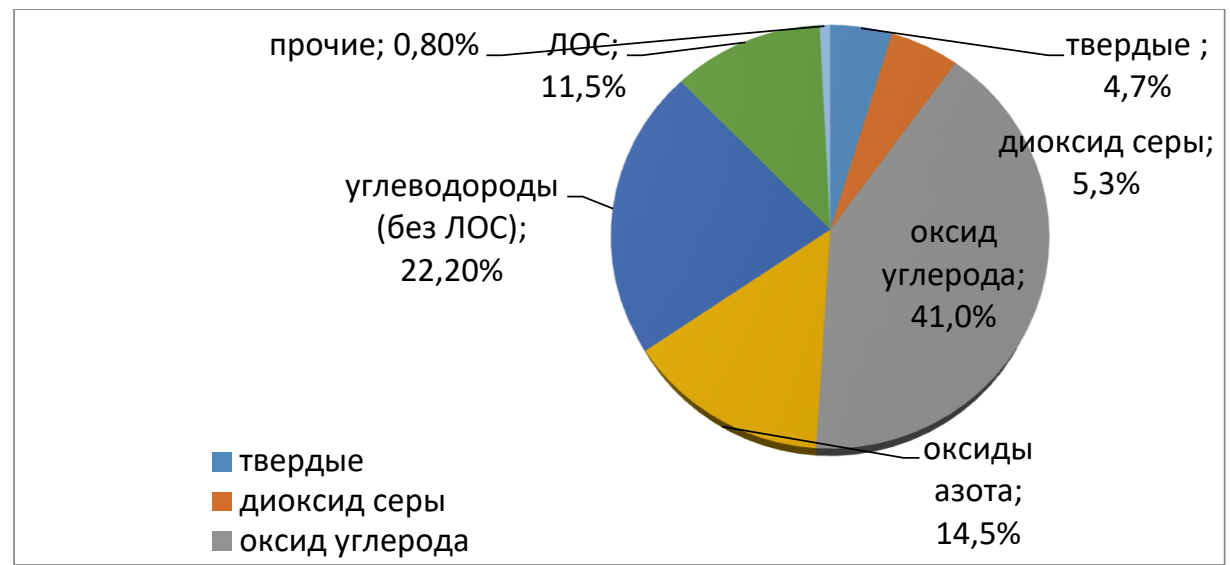

Fig. 1. The gross structure of harmful substances emissions into the atmosphere of the Volgograd region in 2018

As can be seen from Figure 1. The dominant position is occupied by carbon monoxide (41\%) from the total number of harmful substances gross emissions. 
A significant contribution to environmental pollution is made by road transport and the railway network, which are widespread in the Volgograd region. Pollutant emissions from road transport in the Volgograd region annually account for more than $60 \%$ of the total amount. According to the Rospotrebnadzor in the Volgograd region, in 2018 pollutants emissions into the atmosphere accounted for: from road transport 302,3 thousand tons, from railway transport $-10,5$ thousand tons. The problems of urban areas are compounded by an annual increase in the vehicles number. [2, 4-9]. The impurity level concentrations are formed under the influence of the transport, dispersion and leaching pollutants entering the atmospheric air from stationary and mobile sources [2]. However, taking into account the fact that emissions from industrial enterprises go out from the pipes after preliminary cleaning, at a considerable distance from the people breathing zone, the authors conducted experimental studies of gas pollution on the main roads in 8 Volgograd city districts. A map of the technical measurements points is presented in Figure 2 [4-11]. At these points, field studies were carried out, including the route parameters stud, the the traffic flow intensity and its composition, the nature of the adjacent buildings, the meteorological conditions study, the existing green spaces state in the study area, and the carbon monoxide concentration in the curb of the roadway was determined and when distanced from it as the dominant contained in the exhaust gases by the method of calculation the dispersion of harmful substances emissions into the air (MPP-2017), and also data were obtained during the experiment $[11,12]$.

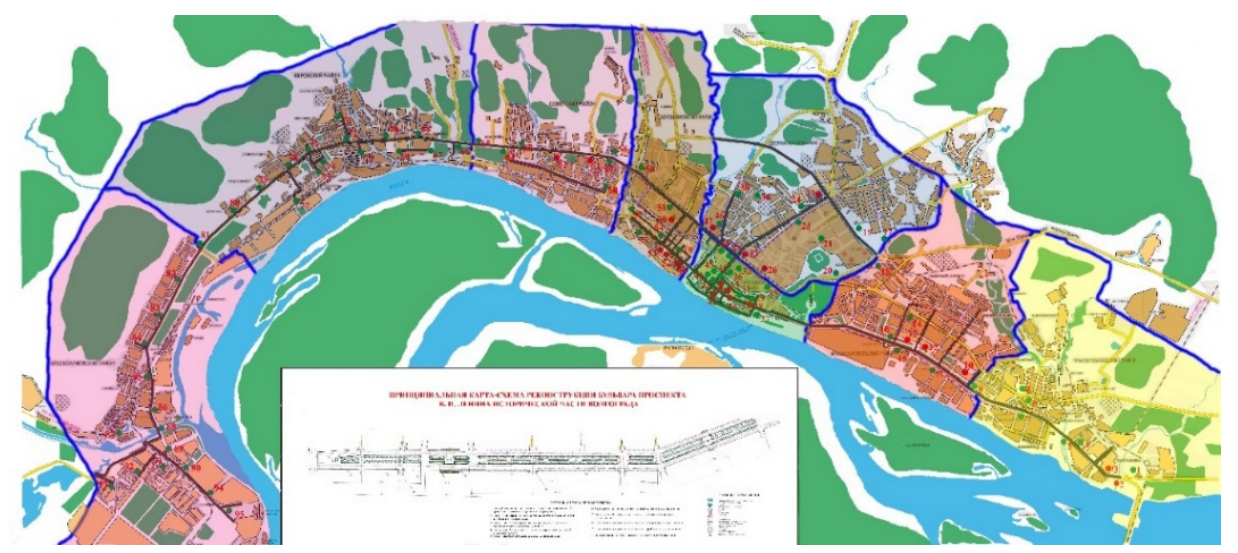

Fig. 2. Map - a scheme of research points of Volgograd road network

According to the reference data of the weather station (M Volgograd Shi) and the aerological Volgograd station (AE Volgograd), the meteorological conditions in the city for 2018 are presented in table 2 [2]. As can be seen from the table, in Volgograd, low speeds are often observed, at which the dispersion of harmful impurities in the air from transport is difficult. The situation is also exacerbated by the tightness of housing, characteristic for Volgograd [13-18]. Obtained data, during field studies and measurements of CO concentration on the roadway curb correlate with the calculated values, and were mathematically processed, the concentration dependence of carbon monoxide on the curb from nine factors was derived, such as:

$\mathrm{L} 3 / 4$ length of area, km; J1 3/4 light car intensity, auto/hour; J2 3/4 truck intensity, auto/h; $\mathrm{Va} 3 / 4$ average speed of traffic flow, auto/h; a $3 / 4$ longitudinal slope of the carriageway, degrees; $j 3 / 4$ relative humidity, degrees; $t 3 / 4$ air temperature, $C ; V_{v}^{3 / 4}$ wind speed, $\mathrm{m} / \mathrm{s} ; \mathrm{q}^{3 / 4}$ wind angle to the road, degrees; $\mathrm{Y0} 3 / 4 \mathrm{CO}$ concentration on the curb; Y10 $3 / 4 \mathrm{CO}$ concentration at a distance of 10 meters from the road..

When considering linear regression for $\mathrm{Y} 0$, the equation was obtained: 
$\mathrm{Y} 0=0,85999+0,00024 \mathrm{~J} 1+0,00036 \mathrm{~J} 2-0,07399 \mathrm{Vv}-0,00461 \mathrm{q}$, the correlation coefficient in this case is $\mathrm{R}=0,72$ significant coefficients of the regression equation.

In the course of the analysis, it was found that of the nine above mentioned factors, the most significant are: $\mathrm{J} 13 / 4$ light car intensity, auto/hour; J2 3/4 truck intensity, auto/h; Vv $3 / 4$ wind speed, $\mathrm{m} / \mathrm{s} ; \mathrm{q} 3 / 4$ wind angle to the road, degrees.

Table 2. Meteorological characteristics in 2018

\begin{tabular}{|c|c|c|c|c|c|c|c|c|c|c|c|c|c|}
\hline \multirow{2}{*}{$\begin{array}{l}\text { Meteorological } \\
\text { characteristics }\end{array}$} & \multicolumn{12}{|c|}{ Months } & \multirow{2}{*}{ Year } \\
\hline & I & II & III & IV & $\mathrm{V}$ & VI & VII & VIII & IX & $X$ & XI & XII & \\
\hline $\begin{array}{l}\text { Precipitation, } \\
\text { number of } \\
\text { days }\end{array}$ & 22 & 16 & 23 & 9 & 7 & 3 & 17 & 2 & 5 & 8 & 7 & 24 & 143 \\
\hline $\begin{array}{l}\text { Repeatability } \\
\text { of } \\
\text { surface } \\
\text { temperature } \\
\text { inversions, \% }\end{array}$ & 32 & 30 & 27 & 37 & 42 & 40 & 40 & 50 & 47 & 33 & 30 & 21 & 36 \\
\hline $\begin{array}{l}\text { Repeatability } \\
\text { of air } \\
\text { stagnation, \% }\end{array}$ & 2 & 4 & - & - & 3 & 3 & 7 & 6 & 6 & 7 & 3 & 3 & 4 \\
\hline $\begin{array}{l}\text { Repeatability } \\
\text { of winds with } \\
\text { the speed } 0-1 \\
\mathrm{~m} / \mathrm{s}\end{array}$ & 16 & 7 & 10 & 13 & 16 & 13 & 10 & 35 & 17 & 29 & 17 & 29 & 18 \\
\hline $\begin{array}{l}\text { Repeatability } \\
\text { of elevated } \\
\text { temperature } \\
\text { inversions, } \%\end{array}$ & 63 & 64 & 65 & 2 & 10 & 12 & 13 & 5 & 3 & 36 & 60 & 66 & 35 \\
\hline $\begin{array}{l}\text { Repeatability } \\
\text { of fogs, } \%\end{array}$ & 10 & 5 & 9 & 0.3 & - & - & - & - & - & 1.4 & 3.5 & 13.3 & 3.5 \\
\hline PZA & 2.5 & & & & & & & & & & & & \\
\hline
\end{tabular}

The data of mathematical analysis, as well as years of research by the authors, confirm that the main factor affecting the distribution of impurities (CO) from automobile transport in the air is the wind regime, namely the speed and wind direction. The most dangerous are so-called air stagnation, when surface temperature inversions are observed at a wind speed of $0-1 \mathrm{~m} / \mathrm{s}$. Because emissions from low and unorganized sources (road transport) accumulate in the atmosphere surface layers, in the immediate vicinity of the people breathing zone and cannot be carried away from the emission source. During air stagnation, all impurities remain in the atmospheric air in the immediate vicinity from the emission source. In cities with a linear configuration, the effect of wind is especially significant. If the wind direction coincides with the city linearity, then there may be an imposition of harmful emissions from various sources of pollution, such as automobile transport and industry, forming increased pollution zones. Thus, the authors established, that at low wind speeds, the highest concentration of carbon monoxide, that enters the atmospheric air with the transport exhaust remains in the immediate vicinity from the emission source.

Another significant factor, affecting the atmospheric gas pollution in the trunk line territories is the intensity of cars and trucks. Moreover, the analysis shows that domestic and imported cars give different pollutants emissions into the atmosphere. The concentration of impurities is also affected by the volume of the internal combustion engine (ICE), the type and volume of the vehicle engine (carburetor, injection, gas) and the fuel type (unleaded petrol, diesel fuel, gas fuel). A comparative analysis showed that the largest gross emissions are given by such cars as: cargo, CIS, carburetor, unleaded petrol, g/p $5-8$ tons; bus, CIS, carburetor, unleaded petrol, g/p 5 - 8 t; bus, CIS, carburetor, unleaded petrol, 
average $8-10 \mathrm{~m}$. Thus, taking into account all of the above factors affecting formation of gas pollution on the Volgograd trunk line territories, it is necessary to improve the monitoring system of linear cities by developing a monitoring points, taking into account the long-term meteorological forecast, as well as taking into account the dispersion nature of pollutants in the atmospheric air from highways. It is necessary to ensure the withdrawal of cargo traffic beyond the residential territory boundaries, to bring the movement of transit heavy trucks outside the city limits on bypass highways.

\section{References}

1. A.V. Antyufeev, G.A. Ptichnikova, Linear city. Urban planning system Big Volgograd, Volgograd, Volgograd State Technical University, 2018.

2. Report on environment state of the Volgograd region in 2018, Volgograd, 2019, 300p.

3. V.F. Sidorenko, Theoretical and methodological foundations of ecological construction, Monograph, VSUACE. Volgograd.

4. State report "On the State of Sanitary and Epidemiological Well-Being of the Population in the Volgograd Region in 2018", Office of the Federal Service for Supervision of Consumer Rights Protection and Human Well-Being in the Volgograd Region, $292 \mathrm{p}$.

5. A.B. Dyakov, Yu.V. Ignatiev, E.P. Konshin, Ecological safety of traffic flows, A.B.Dyakov (Transport, Moscow, 1989).

6. V.N. Azarov, T.V. Dontsova, Sociology of the city, 1, 39-45 (2013).

7. V.N. Azarov, P.A. Sidyakin, T.N. Lopatina, D.A. Nikolenko, Scientific publication Sociology of the city, 1, 28-37 (2014).

8. V.N. Azarov, N.P. Sadovnikova, D.P. Mamontov, Construction and reconstruction, 3, 23-27 (2013).

9. V.L. Bondarenko, V.V. Privalenko, G.M. Skibin, V.N. Azarov, Ecological infrastructure of basin geosystems, Novocherkassk, 2012.

10. Yu.F. Polkovnikov, L.S. Polkovnikova, S.G. Artemova, Yu.P. Ivanova, Materials of the III scientific and technical conference, Volgograd, VSUACE, 2003.

11. Yu.P. Ivanova, IV scientific and technical conf. students, graduate students and young scientists, May 11-14, 2010, Volgograd, Publishing House VSUACE, 2010.

12. "Methods for calculating the dispersion of emissions of harmful (polluting) Approved by order of the Ministry of Natural Resources and Ecology of the RF No. 273 (2017).

13. V.N. Azarov, A.I. Azhgirevich, V.A. Grachev, et al., Industrial ecology (MoscowVolgograd, 2009).

14. T.V. Dontsova, D.S. Khegai Problems of the protection of the industrial and the environment: Sat. materials and scientific environmental engineers, Volgograd, 6, 119122 (2015).

15. V.V. Balakin, Problems of the Russian automobile and road complex: materials of the V intern. scientific and technical Conf., May 21-23, 2008, Penza.

16. A.A. Abroskin, V.F. Sidorenko, Sociology of the city, 1, 27-41 (2017).

17. I.V. Sidorenko, PhD Thesis Volgograd, 2008.

18. N.V. Sapozhkova, PhD Thesis Volgograd, VSUACE, 2012. 